\title{
Age-specific effects of estrogen receptors' polymorphisms on the bone traits in healthy fertile women: the BONTURNO study
}

\author{
Francesco Massart ${ }^{1}$, Francesca Marini ${ }^{2}$, Gerolamo Bianchi ${ }^{3}$, \\ Salvatore Minisola ${ }^{4}$, Giovanni Luisetto ${ }^{5}$, Antonella Pirazzoli 6 , Sara Salvi 6 , \\ Dino Micheli ${ }^{6}$, Laura Masi ${ }^{2}$ and Maria Luisa Brandi*2
}

Address: ${ }^{1}$ Department of Pediatrics, University of Pisa, Pisa, Italy, ${ }^{2}$ Department of Internal Medicine, University of Florence, Florence, Italy, ${ }^{3}$ Rheumatology Unit, Azienda Sanitaria 3, Genova, Italy, ${ }^{4}$ Department of Clinical Sciences, II Clinica Medica, Rome, Italy, ${ }^{5}$ Endocrine Unit, University of Padua, Padua, Italy and ${ }^{6}$ GlaxoSmithKline-Italia, Verona, Italy

Email: Francesco Massart - massart@med.unipi.it; Francesca Marini - f.marini@dmi.unifi.it; Gerolamo Bianchi - gerolamo_bianchi@tin.it; Salvatore Minisola - salvatore.minisola@uniroma1.it; Giovanni Luisetto - giovanni.luisetto@unipd.it;

Antonella Pirazzoli - antonella.a.pirazzoli@gsk.com; Sara Salvi - sara.e.salvi@gsk.com; Dino Micheli - dino.a.micheli@gsk.com;

Laura Masi - l.masi@dmi.unifi.it; Maria Luisa Brandi* - m.brandi@dmi.unifi.it

* Corresponding author

Published: 22 April 2009

Reproductive Biology and Endocrinology 2009, 7:32 doi:10.1/86/1477-7827-7-32

This article is available from: http://www.rbej.com/content/7/1/32

(C) 2009 Massart et al; licensee BioMed Central Ltd.

This is an Open Access article distributed under the terms of the Creative Commons Attribution License (http://creativecommons.org/licenses/by/2.0), which permits unrestricted use, distribution, and reproduction in any medium, provided the original work is properly cited.

\begin{abstract}
Background: Skeletal characteristics such as height $(\mathrm{Ht})$, bone mineral density (BMD) or bone turnover markers are strongly inherited. Common variants in the genes encoding for estrogen receptor alpha (ESRI) and beta (ESR2) are proposed as candidates for influencing bone phenotypes at the population level.

Methods: We studied 64I healthy premenopausal women aged 20-50 years (yrs) participating into the BONTURNO study. Exclusion criteria were irregular cyclic menses, low trauma fracture, metabolic bone or chronic diseases. Serum C-telopeptide of type I collagen (CTX), osteocalcin (OC), and N-terminal propeptide of type I procollagen (PINP) were measured in all enrolled subjects, who underwent to lumbar spine (LS), total hip (TH) and femoral neck (FN) BMD evaluation by DXA. Five hundred seventy Caucasian women were genotyped for ESRI rs2234693 and rs9340799 and ESR2 rs4986938 polymorphisms.
\end{abstract}

Results: Although no genotype differences were found in body parameters, subjects with combined ESR I CCGG plus ESR2 AA-AG genotype were taller than those with opposite genotype $(P=0.044)$. Moreover, ESRI rs2234693 genotypes correlated with family history of osteoporosis (FHO) and hip fracture (FHF) $(\mathrm{P}<0.0 \mathrm{I})$, while ESR2 AA-AC genotypes were strongly associated with FHF (OR $2.387,95 \% \mathrm{Cl}$ I.4323.977; $\mathrm{P}<0.001$ ).

When clustered by age, 20-30 yrs old subjects, having at least one ESRI rs $2234693 \mathrm{C}$ allele presented lower LS- $(P=0.008)$ and TH-BMD $(P=0.047)$ than TT genotypes. In 4I-50 yrs age, lower FN-BMD was associated with ESR2 AA $(P=0.0180)$ subjects than in those with the opposite genotype. ESRI rs2234693 and rs9340799 and ESR2 rs4986938 polymorphisms did not correlate with age-adjusted values of OC, CTX and PINP.

Conclusion: These findings support the presence of age-specific effects of ESR I and ESR2 polymorphisms on various skeletal traits in healthy fertile women. 


\section{Background}

Bone mass increases during the growth period and peaks by young adulthood. Although the greatest gain in bone mass takes place during the accelerated growth in adolescence, bone mineral density (BMD) continues to increase for several years (yrs) later [1].

The importance of peak bone mass as a determinant of osteoporosis and fractures later in life is supported by several studies. For instance, Hui et al. [2] estimated that peak bone mass and postmenopausal bone loss contributed equally to bone status in 70-year-old women. Hernandez et al. [3] estimated that a $10 \%$ increase in peak BMD may delay the development of osteoporosis by 13 yrs.

Low BMD is, indeed, a major determinant of osteoporotic fractures, even though environmental factors, such as dietary intake and physical activity play an important role in the BMD determination. From studies of monozygotic and dizygotic twins, inheritance was estimated to account for $60-80 \%$ of BMD in both men [4] and women [5]. Many other predictors of fragility fracture, bone turnover markers and skeletal geometry are also under genetic control. In the last two decades, an exceptionally wide range of candidate genes have been proposed as risk markers of osteoporosis outcomes [6], but our ability to predict which patients are most likely to sustain low BMD and/or osteoporotic fractures based on genetic screening is still far to be complete.

Among the analyzed candidate genes are those encoding estrogen receptor $\alpha$ (ESR1) and $\beta$ (ESR2). In particular, single nucleotide polymorphisms [7] defined by the restriction enzymes PvuII (rs2234693, C/T) and XbaI (rs9340799, A/G) in the ESR1 intron 1, and by AluI ( $r s 4986938, A / G)$ in the 3'-untraslated region (3'UTR) of ESR2 exon 8 have been evaluated in more than 90 population-based studies, with inconclusive results. For their specific ethnic distribution, clinical predictability of estrogen receptor polymorphisms are strongly dependent on the analysis of homogenous populations [8].

The purpose of this study was to relate skeletal traits such as height (Ht), BMD and bone turnover markers, measured in a large cohort of healthy premenopausal Caucasian women aged 20-50 yrs, to several genotyped polymorphisms in the ESR1 (rs2234693 and rs9340799) and ESR2 (rs4986938) loci.

\section{Methods \\ Subject population}

The analyzed population included all enrolled participants in the Bone Turnover Range of Normality (BONTURNO) study, a multicenter, multiracial/multiethnic cohort study from young adulthood to midlife. The design of the BONTURNO has been described in detail [9]. A total of 641 subjects were enrolled from 20 different centers uniformly distributed across Italy. Each center was asked to recruit four to six healthy individuals for each age range: $20-24,25-29,30-34,34-39,40-44$, and 45-49. A prerequisite for the screening was the presence of regular monthly cyclic menses (cycles occurring every 25-35 days). Subjects were excluded if they had previously suffered a low trauma fracture (as judged by the investigator), any metabolic bone diseases, or chronic diseases capable to influence bone metabolism (malignancies, rheumatoid arthritis, diabetes, etc.). Subjects were also excluded if abnormal laboratory results in serum calcium, creatinine, phosphate, and magnesium were found upon screening.

The study sites received formal approval from the local Ethics Committees and obtained signed informed consent from each subject before enrolment.

\section{Clinical examination}

The subjects considered to be eligible for inclusion in the study were asked to come to the outpatient clinic by 7:308:30 a.m. in fasting condition for the collection of a blood sample. Six aliquots of serum samples were separated and kept on dry ice during transportation by courier to Interlab (Munich, Germany), where they were kept at $-80^{\circ} \mathrm{C}$ for the later measurements of bone turnover markers in all subjects, and of follicle stimulating hormone (FSH) and serum estradiol in women aged $>39 \mathrm{yrs}$. It was preplanned that women with FSH levels $>30 \mathrm{IU} / \mathrm{L}$, despite menstruating normally, would be analyzed separately and defined as "perimenopausal".

After breakfast, organized locally, a Dual X-ray (DXA) evaluation was carried out and a multi-item questionnaire administrated. Hologic ( 20 centers) and Lunar (3 centers) instruments were used for DXA evaluation of BMD at the lumbar spine (LS), femoral neck (FN) and total hip (TH). The values obtained with Lunar instruments were standardized to Hologic instruments [10]. The questionnaire included personal data and evaluated factors that potentially influence bone turnover, including general health and any type of continuous use of drugs (including oral contraceptives or calcium supplements), fracture history, family (i.e. first degree relative) history of low-energy fractures and/or of osteoporosis (defined by LS- and/or FN$\mathrm{BMD}<-2.0 \mathrm{SDS}$ ), number of pregnancies, smoking, alcohol consumption, sunlight exposure and menstrual cycle day. In all subjects body $\mathrm{Ht}$ and weight were assessed (Harpender stadiometer) and the body mass index (BMI, $\left.\mathrm{kg} / \mathrm{m}^{2}\right)$ was derived.

The bone turnover markers investigated in this study were serum C-telopeptide of type I collagen (CTX), osteocalcin (OC), and N-terminal propeptide of type I procollagen 
(P1NP). The three bone turnover markers, FSH, and estradiol were measured by automated immunoassay with the ECLIA device from Roche Diagnostics (Palo Alto, CA, USA). The coefficients of variation (interassay) provided by Interlab ranged from 7 to $14 \%$. Additional biochemical tests performed by local laboratories included serum calcium, creatinine, phosphate, and magnesium.

\section{Genotyping}

Genomic DNA was extracted from peripheral blood lymphocytes using a column microvolume system (NucleoSpin Blood Quick Pure, Macherey-Nagel, Easton, PA, USA) according to the manufacturer's instructions. Genomic DNA regions of ESR1 and ESR2 genes, containing the above described polymorphisms were analyzed by polymerase chain reactions (PCR), using specific couples of primers designed by Primer3 (v.0.4.0) program, freely available [11].

\section{ESRI gene polymorpisms}

Intron 1 region containing both the $r s 2234693$ and rs9340799 polymorphisms has been amplified by PCR in a final volume of $50 \mu \mathrm{l}$ containing $1 \times$ of reaction buffer, $0.4 \mu \mathrm{M}$ of each primer, $0.2 \mathrm{mM}$ of dNTPs, $1 \mathrm{U}$ of GoTaq ${ }^{\circledR}$ DNA Polymerase (Promega, Madison, WI - USA) and about 50 ng of genomic DNA. Thermal cycling conditions were $94^{\circ} \mathrm{C}$ for $5 \mathrm{~min}, 35$ cycles of $94^{\circ} \mathrm{C}$ for $30 \mathrm{sec}, 60^{\circ} \mathrm{C}$ for $30 \mathrm{sec}$ and $72^{\circ} \mathrm{C}$ for $1 \mathrm{~min}$, followed by an additional $72^{\circ} \mathrm{C}$ for $5 \mathrm{~min}$ stabilization step. Two aliquots of PCR products were separately digested overnight at $37^{\circ} \mathrm{C}$ with 1 U of PvuII or XbaI (MBI Fermentas, Vilnius, Lithuania). PvuII digestion products were visualised by $3 \%$ ethidium bromide stained agarose gel electrophoresis. Fragments were separated depending on their length revealing presence or absence of the restriction site and identifying respectively the $T$ and the $C$ alleles. Similarly, XbaI digestion products were visualised by $3 \%$ ethidium bromide stained agarose gel electrophoresis. Fragments were separated depending on their length revealing presence or absence of the restriction site and identifying respectively the $A$ and the $G$ alleles.

\section{ESR2 gene polymorphism}

PCR amplification was performed in a final volume of 50 $\mu \mathrm{l}$ containing $1 \times$ of reaction buffer, $0.4 \mu \mathrm{M}$ of each primer, $0.2 \mathrm{mM}$ of dNTPs, $1 \mathrm{U}$ of GoTaq ${ }^{\circledR}$ DNA Polymerase (Promega, Madison, WI - USA) and about $50 \mathrm{ng}$ of genomic DNA. Thermal cycling conditions were $94^{\circ} \mathrm{C}$ for $5 \mathrm{~min}, 35 \mathrm{cycles}$ of $94^{\circ} \mathrm{C}$ for $30 \mathrm{sec}, 60^{\circ} \mathrm{C}$ for $30 \mathrm{sec}$ and $72^{\circ} \mathrm{C}$ for $30 \mathrm{sec}$, followed by an additional $72^{\circ} \mathrm{C}$ for $5 \mathrm{~min}$ stabilization step. The 168 bp PCR product was digested over-night at $37^{\circ} \mathrm{C}$ with $1 \mathrm{U}$ of AluI endonuclease (MBI Fermentas, Vilnius, Lithuania). AluI digestion products were visualised by $3 \%$ ethidium bromide stained agarose gel electrophoresis. Fragments were separated depending on their length revealing presence or absence of the restriction site and identifying respectively the $A$ and the $G$ alleles.

\section{Statistical analyses}

Data were expressed as mean \pm standard deviation (SD) unless otherwise stated. Statistical evaluation was performed using standard Chi-squared $\left(\chi^{2}\right)$ test, one-way analysis of variance (ANOVA) and Pearson's correlation $(r)$ where multiple samples were obtained. When two sets of data were compared, an unpaired Student's $t$-test was employed. A two-tailed significance test was used for all comparisons. Standard $\chi^{2}$ test was also used to compare observed genotype frequencies with those expected under the Hardy-Weinberg (HW) equilibrium [12]. $P<0.05$ was considered statistically significant. All analyses were performed using the SAS statistical package, version 8.2 (SAS Institute, Cary, NC).

\section{Results}

A total of 641 healthy premenopausal women meeting the inclusion and exclusion criteria were recruited from 20 investigative sites. Two women were excluded due to serum calcium $>10.5 \mathrm{mg} / \mathrm{dL}$ and one patient for P1NP and OC levels three times above the upper normal range, who is now under investigation for suspected Paget disease of the bone. No other patients had abnormal values of serum phosphate, magnesium or creatinine (data not shown).

Serum FSH >30 IU/L was found in 18 women even though menstruating normally. They are considered per protocol as perimenopausal. Twelve subjects were on treatment with stable doses of thyroxine, 11 on antihyperthensive agents not associated with diuretics, 3 on serotonin-uptake inhibitors, and 2 on proton pump inhibitors. Eighty-three women were on oral contraceptive treatment [9].

Genetic data were available for 573 enrolled subjects. Three non-Caucasian women were excluded from genetic analyses and their exclusion did not modify the results of the study (data not shown). Statistical analysis was performed on the remaining 570 Caucasian women who were not on treatment with known bone-active drugs.

The general characteristics of the study population on the basis of allelic variability for ESR1 and ESR2 loci are described in Table 1. According to [12], genotype distributions of these two loci were found to be in HW equilibrium (data not shown), suggesting that the enrolled subjects represented a homogeneous genetic background. No difference was evidenced in ESR1 and ESR2 loci for all considered variables, though a tendency to on increased Ht and a delayed menarche age were detected for ESR1 
Table I: Genotype variability for ESRI and ESR2 loci in the $\mathbf{5 7 0}$ Caucasian women enrolled in the BONTURNO study.

\begin{tabular}{lc}
\hline Locus & Women $(\mathbf{n}=\mathbf{5 7 0})$ \\
\hline ESRI rs2234693 & \\
CC (n [\%]) & $123(21.6)$ \\
CT (n [\%]) & $287(50.3)$ \\
TT (n [\%]) & $160(28.1)$ \\
ESRI rs9340799 & \\
AA (n [\%]) & $203(35.6)$ \\
AG (n [\%]) & $272(47.7)$ \\
GG (n [\%]) & $95(16.7)$ \\
ESR2 rs4986938 & \\
AA (n [\%]) & $92(16.2)$ \\
AG (n [\%]) & $266(46.7)$ \\
GG (n [\%]) & $212(16.7)$ \\
\hline
\end{tabular}

rs2234693 CC, rs9340799 GG or CCGG, and ESR2 AA genotypes than for the opposites $(P>0.05$, data not shown). Moreover, the combination of ESR1 CCGG plus ESR2 AA$A G$ genotype was significantly taller $(164.2 \pm 6.06 \mathrm{~cm})$ than ESR1 TTAA plus ESR2 GG genotype $(161.7 \pm 6.74$ $\mathrm{cm} ; P=0.044)$. When ESR1 and ESR2 genotypes were evaluated alone or in combination, no significant correlation was observed with weight, BMI, heart rate and blood pressure $(P>0.05)$.

Regarding family history of osteoporosis (FHO) and of hip fracture (FHF), no significative association was found with single or combined analysis of ESR1 polymorphisms. In subjects positive both for FHO and for FHF, the 3 ESR1 rs2234693 genotypes (but not the rs9340799) were differently distributed than in subjects with double negative FHO-FHF $\left(\chi^{2}=10.957, P<0.01\right.$; Table 2$)$, with odds ratio (OR) of founding ESR1 CT-TT genotypes in double positive FHO-FHF being 1.836 (95\% CI $0.860-$ 3.919, $P=0.06)$. No significant association was detected combining both ESR1 polymorphisms $(P>0.05)$. Furthermore, ESR2 rs4986938 genotypes correlated with FHF $\left(\chi^{2}=11.881, P<0.01\right)$ but not with FHO $(P>0.05)$, as having at least one ESR2 rs4986938 A allele correlated both with positive FHF $\left(\chi^{2}=11.550, P<0.001\right.$; OR 2.387, 95\% CI 1.432-3.977) and with double positive FHO-FHF $\left(\chi^{2}=9.407, P<0.005\right.$; OR 2.871, 95\% CI 8.804-35.403) (Table 2). No association was detected co-analyzing ESR1 and ESR2 genotypes $(P>0.05)$.

The 570 enrolled women were divided in 3 age groups: from 20 to 30 yrs (class 1), from 31 to 40 yrs (class 2) and from 41 to 50 yrs (class 3 ) (Table 3 ). In class 1 , subjects having at least one ESR1 rs2234693 C allele (i.e. CC and CT genotypes) presented lower LS-BMD $(1.023 \pm 0.112 \mathrm{~g} /$ $\left.\mathrm{cm}^{2}\right)$ and TH-BMD $\left(0.927 \pm 0.122 \mathrm{~g} / \mathrm{cm}^{2}\right)$ than TT genotypes, respectively (LS-BMD $1.077 \pm 0.131 \mathrm{~g} / \mathrm{cm}^{2}, P=$ 0.0083 ; TH-BMD $\left.0.969 \pm 0.121 \mathrm{~g} / \mathrm{cm}^{2}, P=0.0474\right)$. Similar but not significant trends were detected in classes 2 and 3. In class 3, TH-BMD $\left(0.860 \pm 0.111 \mathrm{~g} / \mathrm{cm}^{2}\right)$ and FN$\operatorname{BMD}\left(0.738 \pm 0.108 \mathrm{~g} / \mathrm{cm}^{2}\right)$ of ESR2 rs4986938 AA genotype were lower than the opposite GG ones (TH-BMD $0.923 \pm 0.130 \mathrm{~g} / \mathrm{cm}^{2}, P=0.0227 ;$ FN-BMD $0.798 \pm 0.119$ $\left.\mathrm{g} / \mathrm{cm}^{2}, P=0.0180\right)$. Regarding LS-, TH- or FN-BMD, no other signifivative differences were observed co-analyzing ESR1 and ESR2 loci.

According to previously published data, oral contraceptive users and 18 women considered in perimenopausal phase for serum FSH levels $>30 \mathrm{IU} / \mathrm{mL}$ were excluded from statistic analysis for bone turnover markers [9]. Age class-adjusted levels of serum OC, CTX and P1NP did not segregate with ESR1 and ESR2 loci $(P>0.05)$. Furthermore, no differences between ESR1 and ESR2 polymorphisms, were detected for serum age class-adjusted levels of calcium, phosphate and magnesium $(P>0.05)$.

\section{Discussion}

Low $\mathrm{BMD}$ is a major risk factor for spine and proximal femur fractures $[13,14]$. In women, BMD in adulthood is largely determined by the amount of bone accumulated at the end of their skeletal growth (peak bone mass), their rate of bone loss after menopause when ovaries cease pro-

Table 2: Family history of osteoporosis (FHO) and of hip fracture (FHF) regarding ESRI and ESR2 genotypes.

\begin{tabular}{|c|c|c|c|c|c|c|}
\hline & FHO & FHF & FHO-FHF & FHO & FHF & FHO-FHF \\
\hline & \multicolumn{3}{|c|}{ positive } & \multicolumn{3}{|c|}{ negative } \\
\hline \multicolumn{7}{|c|}{ ESRI rs2234693 } \\
\hline CC (n [\%]) & $39(17.6)$ & $18(17.6)$ & $9(14.7)$ & $77(24.0)$ & $98(22.1)$ & $68(24.1)$ \\
\hline CT (n [\%]) & $118(53.1)$ & $50(49.1)$ & $32(52.5)$ & $158(49.0)$ & $227(5 \mid .2)$ & $|4|(50.0)$ \\
\hline TT (n [\%]) & $65(29.3)$ & $34(33.3)$ & $20(32.8)$ & $87(27.0)$ & I I 8 (26.7) & $73(25.9)$ \\
\hline Total & 222 & 102 & 61 & 322 & 443 & 282 \\
\hline \multicolumn{7}{|c|}{ ESR2 rs4986938 } \\
\hline $\mathrm{AA}(\mathrm{n}[\%])$ & $36(16.3)$ & $18(18.2)$ & $12(19.7)$ & $50(15.8)$ & $68(15.5)$ & $44(15.8)$ \\
\hline AG (n [\%]) & $104(47.1)$ & $59(59.6)$ & $38(62.3)$ & $119(37.5)$ & $193(44.0)$ & $127(45.5)$ \\
\hline GG (n [\%]) & $81(36.6)$ & $22(22.2)$ & II (I8.0) & 148 (46.7) & $178(40.5)$ & $108(38.7)$ \\
\hline Total & 221 & 99 & 61 & 317 & 439 & 279 \\
\hline
\end{tabular}


Table 3: Mean age-class adjusted values (SD) of LS-, TH- and FN-BMD regarding ESRI and ESR2 genotypes.

\begin{tabular}{|c|c|c|c|c|c|c|c|c|c|}
\hline Age classes & \multicolumn{3}{|c|}{1} & \multicolumn{3}{|c|}{2} & \multicolumn{3}{|c|}{3} \\
\hline Subjects (n) & \multicolumn{3}{|c|}{158} & \multicolumn{3}{|c|}{192} & \multicolumn{3}{|c|}{219} \\
\hline Age range (yrs) & \multicolumn{3}{|c|}{$20-30$} & \multicolumn{3}{|c|}{$31-40$} & \multicolumn{3}{|c|}{$4 I-50$} \\
\hline $\mathrm{BMD}(\mathrm{g} / \mathrm{cm} 2)$ & LS & TH & FN & LS & TH & FN & LS & TH & FN \\
\hline \multicolumn{10}{|l|}{ ESRI rs2234693 } \\
\hline $\mathrm{CC}$ & $\begin{array}{c}1.063 \\
(0.134)\end{array}$ & $\begin{array}{c}0.941 \\
(0.117)\end{array}$ & $\begin{array}{c}0.859 \\
(0.150)\end{array}$ & $\begin{array}{c}1.075 \\
(0.138)\end{array}$ & $\begin{array}{c}0.906 \\
(0.098)\end{array}$ & $\begin{array}{c}0.821 \\
(0.125)\end{array}$ & $\begin{array}{c}1.021 \\
(0.122)\end{array}$ & $\begin{array}{c}0.902 \\
(0.115)\end{array}$ & $\begin{array}{c}0.778 \\
(0.122)\end{array}$ \\
\hline $\mathrm{CT}$ & $\begin{array}{c}1.025 \\
(0.1 / 2)\end{array}$ & $\begin{array}{c}0.930 \\
(0.120)\end{array}$ & $\begin{array}{c}0.845 \\
(0.116)\end{array}$ & $\begin{array}{c}1.067 \\
(0.122)\end{array}$ & $\begin{array}{c}0.906 \\
(0.117)\end{array}$ & $\begin{array}{c}0.795 \\
(0.118)\end{array}$ & $\begin{array}{c}1.041 \\
(0.127)\end{array}$ & $\begin{array}{c}0.905 \\
(0.127)\end{array}$ & $\begin{array}{c}0.789 \\
(0.115)\end{array}$ \\
\hline TT & $\begin{array}{c}1.077 \\
(0.131)\end{array}$ & $\begin{array}{c}0.969 \\
(0.121)\end{array}$ & $\begin{array}{c}0.874 \\
(0.129)\end{array}$ & $\begin{array}{c}1.059 \\
(0.106)\end{array}$ & $\begin{array}{c}0.928 \\
(0.105)\end{array}$ & $\begin{array}{c}0.813 \\
(0.118)\end{array}$ & $\begin{array}{c}1.049 \\
(0.125)\end{array}$ & $\begin{array}{c}0.904 \\
(0.124)\end{array}$ & $\begin{array}{c}0.777 \\
(0.122)\end{array}$ \\
\hline \multicolumn{10}{|l|}{ ESR2 rs4986938 } \\
\hline $\mathrm{AA}$ & $\begin{array}{c}1.039 \\
(0.130)\end{array}$ & $\begin{array}{c}0.932 \\
(0.110)\end{array}$ & $\begin{array}{c}0.846 \\
(0.112)\end{array}$ & $\begin{array}{c}1.059 \\
(0.123)\end{array}$ & $\begin{array}{c}0.922 \\
(0.110)\end{array}$ & $\begin{array}{c}0.814 \\
(0.122)\end{array}$ & $1.044(0.147)$ & $0.860(0.111)$ & $\begin{array}{c}0.738 \\
(0.108)\end{array}$ \\
\hline AG & $\begin{array}{c}1.044 \\
(0.126)\end{array}$ & $\begin{array}{c}0.935 \\
(0.125)\end{array}$ & $\begin{array}{c}0.847 \\
(0.131)\end{array}$ & $\begin{array}{c}1.076 \\
(0.117)\end{array}$ & $\begin{array}{c}0.910 \\
(0.106)\end{array}$ & $\begin{array}{c}0.804 \\
(0.110)\end{array}$ & $1.032(0.128)$ & $0.900(0.118)$ & $\begin{array}{c}0.784 \\
(0.118)\end{array}$ \\
\hline GG & $\begin{array}{c}1.056 \\
(0.121)\end{array}$ & $\begin{array}{c}0.963 \\
(0.122)\end{array}$ & $\begin{array}{c}0.870 \\
(0.135)\end{array}$ & $\begin{array}{c}1.056 \\
(0.125)\end{array}$ & $\begin{array}{c}0.911 \\
(0.115)\end{array}$ & $\begin{array}{c}0.806 \\
(0.132)\end{array}$ & $1.046(0.115)$ & $0.923(0.130)$ & $\begin{array}{c}0.798 \\
(0.119)\end{array}$ \\
\hline
\end{tabular}

ducing estrogens, and age-related bone loss. It has been well established with the study of twins, that peak bone mass is highly heritable with an estimated heritability between 0.50 and 0.80 [15]. Conversely, published data on the heritability of bone loss at menopause are conflicting [16-18]. Therefore, BMD is a trait that lends itself to studies designed to identify the genes underlying its normal variation $[16,17,19]$.

The past decade has seen an important increase in the use of association studies with candidate genes for the genetic analysis of complex traits such as BMD and/or fracture risk. Many genes have been examined for their association with normal BMD variation, which yields an ever-expanding candidate gene list. However, this approach has been largely criticized because of discrepancy in the results $[20,21]$, often related to the small size of the enrolled cohorts. Moreover, most of the studies focused on postmenopausal female populations. In this view, the main purpose of the present study was to evaluate allelic influence of target genes, such as estrogen receptors, on inherited skeletal traits in a large and homogeneous population-based cohort of premenopausal healthy Caucasian women [9].

For ESR1 and ESR2, two genes worldwide evaluated by independent research groups, the results obtained even if compelling for their involvement in $\mathrm{BMD}$, osteoporosis, or fracture, are, however, not conclusive [22]. Confounding factors encompassed ethnic-specific distribution of ESR1 and ESR2 polymorphisms [8,23,24]. For example, in the SWAN study [23] which enrolled 693 Caucasian participants (366 premenopausal women), specific associations of BMD with ESR1 and ESR2 genotypes varied according to race/ethnicity. Furthermore, 4 independent studies [24] concluded that ESR2 locus could be involved in FN-BMD in Caucasians, LS-BMD in Japanese postmenopausal women, and LS- and FN-BMD in Chinese premenopausal women. In addition, most of the human studies of genetic association with BMD have been crosssectional, and only very few studies examined the association of the genotypes to BMD change within specific age ranges. For all these reasons the present study was aiming to compare the results obtained for ESR1 and ESR2 to other data obtained in age-equivalent studies in Caucasian women, examining the relation of ESR1 and ESR2 genes' polymorphisms.

Differently than for the ESR2 locus [25], allelic variants of ESR1 gene were proposed to affect skeletal growth, through a genotype-dependent estrogen sensitivity at the growth cartilage, with the ESR1 $p x$ haplotype being less sensitive to estrogen effects [26]. The ESR1 haplotype effect was supported by functional studies $[27,28]$ and by multiple association analysis documented for this gene variant [29-33]. For example, body $\mathrm{Ht}$ in pre- and postmenopausal women [29] and estradiol levels in premenopausal women were lower [30], with the number of copies of ESR1 px haplotype in their genotype. Lorentzon et al. [31] found an association between reduced Ht and $P v u I I T$ and $X b a$ I $A$ alleles, which corresponded to the ESR1 $p x$ haplotype. Although this study was performed in adolescent boys [31], it is in line with other findings in adult women. In 607 Caucasian women (aged 55-80 yrs) in whom vertebral fractures were excluded, Schuit et al. [29] observed significant association between $\mathrm{Ht}$ and ESR1 PvuII-XbaI haplotypes. In contrast to [32], a significant allele dose effect was observed for ESR1 $p x$ haplotype, corresponding to a $0.9-\mathrm{cm}$ decrease in Ht per allele copy $(P$ for trend $=0.02)$, extreme genotypes varied $1.8 \mathrm{~cm}$. 
Boot et al. [33] partially confirmed this allele dose-effect to some extent, as in girls heterozygous for ESR1 px haplotype the Ht was higher than in those homozygous for the ESR1 $p x$ haplotype. In our series, higher $\mathrm{Ht}$ was slightly $(P>0.05)$ correlated with ESR1 CC, GG or CCGG, and ESR2 AA genotypes, while ESR1 CCGG plus ESR2 AA$A G$ genotype was significantly $(2.5-\mathrm{cm})$ taller than the opposite genotype. As ESR2 modulates ESR1 transcriptional activity [34], this novel biological interaction between ESR2 and ESR1 genotypes is not surprising.

Family history is a major risk factor for osteoporotic fractures [35]. In white postmenopausal women, increased BMD-independent risk for vertebral (but not non-vertebral) fractures was found in ESR1 $p x$ haplotype carriers [26]. Moreover, the GENOMOS Consortium found a BMD-independent protective effect against vertebral fractures in ESR1 XX homozygous individuals, while no effects on fracture risk were seen for ESR1 PvuII polymorphism [22]. Similarly to the InCHIANTI study [36], we could not demonstrate any strong association between FHF and ESR1 rs2234693 and rs9340799 genotypes. However, our study might have had not enough power to detect any differences.

Variants of ESR2 gene, alone and in interaction with ESR1 genotypes influenced the fracture risk in postmenopausal women. Moron et al. [37] suggested that ESR2 rs4986938 (but not ESR1 rs2234693) could have a role $(P=0.04)$ in osteoporosis in Spanish postmenopausal women. Furthermore, they detected a joint effect of ESR1 gene in osteoporosis modulating the penetrance of ESR2 rs4986938 genotype [37]. Rivadeneira et al. [38] showed for the first time that white postmenopausal women ( $\geq 55$ yrs of age) who are homozygous for a common intron 2-3'UTR ESR2 haplotype allele have 40-80\% increased risk of fragility and vertebral fracture. Interestingly, we also observed ESR2 rs4986938 genotypes significantly correlated with FHF risk but not with FHO, suggesting ESR2 variants may affect bone strength independently of BMD.

According to our findings, McGuigan et al. [39] observed a modest association between ESR1 PvuII genotypes and BMD at the hip $(P=0.034)$ but not at the spine in 216 young Irish women (mean age $22.6 \pm 1.6 \mathrm{yrs}$ ), with no differences regarding the ESR1 XbaI locus [39]. On the other hand, Valero et al. [40] found no significant relations between FN- or LS-BMD with both ESR1 PvuII and XbaI loci in 194 older Caucasian women aged 22-45 yrs. Furthermore, a cross sectional study of XbaI and BMD in women who were premenopausal and perimenopausal, did not confirm this association [41]. Finally, in perimenopausal Caucasian women (older than 48.5 yrs) enrolled in the GENOMOS consortium, none of two ESR1 intron 1 polymorphisms (i.e. PvuII and XbaI loci) or derived hap- lotypes had any statistically significant effect on BMD, with estimated differences between genetic contrasts being $0.01 \mathrm{~g} / \mathrm{cm}^{2}$ or less [22]. Collectively, our findings and the published studies [22,39-41] make possible to support a significant effects of the ESR1 rs2234693 (but not rs9340799) locus on the BMD mainly in the young adult next to her achievement of bone peak mass.

Previous approaches have also suggested the role of ESR2 in BMD within different ethnic backgrounds [24]. No association between ESR2 rs4986938 with LS- or FN-BMD were detected in 1291 Caucasian women (from 192 families) aged $33.2 \pm 7.1$ yrs (range 20-50 yrs) [42]. Similarly, no associations between ESR2 rs4986938 genotypes and Ht, LS-BMD and serum OC levels were detected in 147 healthy peri and postmenopausal Greek women (mean age $54 \pm 7.9$ yrs) [25]. On the other hand, we detected significant BMD variations of the ESR2 rs4986938 genotypes only in the later age group (i.e. 41-50 yrs old women). Together with ESR1 rs2234693 data, this reinforces the hypothesis that ESR1 and ESR2 genes affect bone metabolism in precise and distinct age-sequential windows. Larger pre-planned analysis will be necessary to confirm our interpretation.

In conclusion, taken together, our findings indicated that, although the effect size may be small, allelic variations in ESR1 and ESR2 genes are associated with various and different bone traits (e.g. Ht, BMD and FHF risk) in normal premenopausal Caucasian subject. Furthermore, multiple genotype interactions were detected that reinforced the polygenic and complex character of skeletal system. In some cases however, the mean pattern of bone trait values for a gene polymorphism with evidence of association was not in agreement with previously published studies. Therefore, even though family history of fragility fractures is one of the risk factors [35], we cannot recommend genetic testing for clinical use in humans to better identify population at risk for pathologic bone traits such as fragility fractures. However, as it has been shown for other diseases [43], extended panels of several polymorphic markers could be used in the future, in addition to traditional risk factors, to evaluate the skeletal disorder risk in humans.

\section{Competing interests}

All authors participating to the BONTURNO study, and then to the preparation of this manuscript, did not have competing interests regarding the present data.

\section{Authors' contributions}

Both FM carried out the molecular genetic studies, performed the statistical analysis and drafted the manuscript. LM participated in the sequence alignment. GB, SM, GL and LM carried out the subject enrolment and their clini- 
cal evaluation. AP, SS and DM participated in the design of the study and in the subject data collection. MLB conceived of the study, and participated in its design and coordination and helped to draft the manuscript. All authors read and approved the final manuscript.

\section{Acknowledgements}

The BONTURNO Study and the genetic research were supported by GlaxoSmithKline-Italia (Verona, Italy). All study contributors and their location (in alphabetical order) were: Silvano Adami (Verona), Maurizio Bevilacqua (Milano), Gerolamo Bianchi (Genova), Ottavio Bosello (Verona), Maria Luisa Brandi (Firenze), Francesco Cantatore (Foggia), Ombretta Di Munno (Pisa), Erio Fiore (Catania), Bruno Frediani (Siena), Giorgio Gandolini (Milano), Sandro Giannini (Padova), Vincenzo Lo Cascio (Verona), Giovanni Luisetto (Padova), Claudio Marcocci (Pisa), Salvatore Minisola (Roma), Maurizio Muratore (Lecce), Ranuccio Nuti (Siena), Sergio Ortolani (Milano), Gian Battista Rini (Palermo), Maurizio Rossini (Verona), Fabio Massimo Ulivieri (Milano).

\section{References}

I. Henry YM, Fatayerji D, Eastell R: Attainment of peak bone mass at the lumbar spine, femoral neck and radius in men and women: relative contributions of bone size and volumetric bone mineral density. Osteoporos Int 2004, I 5:263-273.

2. Hui SL, Slemenda CW, Johnston CC Jr: The contribution of bone loss to postmenopausal osteoporosis. Osteoporos Int 1990, I:30-34.

3. Hernandez CJ, Beaupré GS, Carter DR: A theoretical analysis of the relative influences of peak BMD, age-related bone loss and menopause on the development of osteoporosis. Osteoporos Int 2003, 1 4:843-847.

4. Gennari L, Brandi ML: Genetics of male osteoporosis. Calcif Tissue Int 200I, 69:200-204.

5. Brandi ML: Management of post-menopausal osteoporosis: something new on the horizon? J Endocrinol Invest 2003, 26:170-173.

6. Massart F, Reginster JY, Brandi ML: Genetics of menopause-associated diseases. Maturitas 200I, 40:103-116.

7. [http://www.ncbi.nlm.nih.gov/projects/SNP/].

8. Massart F, Marcucci G, Brandi ML: Pharmacogenetics of bone treatments: the VDR and ERalpha gene story. Pharmacogenomics 2008, 9:733-746.

9. Adami S, Bianchi G, Brandi ML, Giannini S, Ortolani S, Dimunno O, Frediani B, Rossini M, On behalf of the BONTURNO study group: Determinants of Bone Turnover Markers in Healthy Premenopausal Women. Calcif Tissue Int 2008, 82:34I-347.

10. Lu Y, Fuerst T, Hui S, Genant HK: Standardization of bone mineral density at femoral neck, trochanter and Ward's triangle. Osteoporos Int 200I, I 2:438-444.

I1. [http://frodo.wi.mit.edu/cgi-bin/primer3/primer3.cgi/].

12. Becherini L, Gennari L, Masi L, Mansani R, Morelli A, Falchetti A, Massart F, Gonnelli S, Cepollaro C, Tanini A, Brandi ML: Evidence of a linkage disequilibrium between polymorphisms in the human estrogen receptor alpha gene and their relationship to bone mass variation in postmenopausal Italian women. Hum Mol Genet 2000, 9:2043-2050.

13. Melton LJ 3rd, Atkinson EJ, O'Fallon WM, Wahner HW, Riggs BL: Long-term fracture prediction by bone mineral assessed at different skeletal sites. J Bone Miner Res 1993, 8: I227-I 233.

14. Marshall D, Johnell O, Wedel H: Meta-analysis of how well measures of bone mineral density predict occurrence of osteoporotic fractures. BM] 1996, 3 I 2: I254- I259.

15. Pocock NA, Eisman JA, Hopper JL, Yeates MG, Sambrook PN, Eberl S: Genetic determinants of bone mass in adults. A twin study. J Clin Invest 1987, 80:706-7I0.

16. Brown LB, Streeten EA, Shapiro JR, McBride D, Shuldiner AR, Peyser PA, Mitchell BD: Genetic and environmental influences on bone mineral density in pre- and post-menopausal women. Osteoporos Int 2005, 16:1849-1856.

17. Hunter DJ, de Lange M, Andrew T, Snieder H, MacGregor AJ, Spector TD: Genetic variation in bone mineral density and calcaneal ultrasound: a study of the influence of menopause using female twins. Osteoporos Int 200I, I 2:406-4II.

18. Ralston SH: Genetic control of susceptibility to osteoporosis. J Clin Endocrinol Metab 2002, 87:2460-2466.

19. Danielson ME, Cauley JA, Baker CE, Newman AB, Dorman JS, Towers JD, Kuller LH: Familial resemblance of bone mineral density (BMD) and calcaneal ultrasound attenuation: the BMD in mothers and daughters study. I Bone Miner Res 1999, 14:102-110.

20. Colhoun HM, McKeigue PM, Davey Smith G: Problems of reporting genetic associations with complex outcomes. Lancet 2003 , 36I:865-872.

21. Tabor HK, Risch NJ, Myers RM: Candidate-gene approaches for studying complex genetic traits: practical considerations. Nat Rev Genet 2002, 3:39I-397.

22. Ioannidis JP, Ralston SH, Bennett ST, Brandi ML, Grinberg D, Karassa FB, Langdahl B, van Meurs JB, Mosekilde L, Scollen S, Albagha OM, Bustamante M, Carey AH, Dunning AM, Enjuanes A, van Leeuwen JP, Mavilia C, Masi L, McGuigan FE, Nogues X, Pols HA, Reid DM, Schuit SC, Sherlock RE, Uitterlinden AG, GENOMOS Study: Differential genetic effects of ESRI gene polymorphisms on osteoporosis outcomes. JAMA 2004, 292:2I05-2II4.

23. Greendale GA, Chu J, Ferrell R, Randolph JF Jr, Johnston JM, Sowers MR: The association of bone mineral density with estrogen receptor gene polymorphisms. Am J Med 2006, I I 9:S79-S86.

24. Shearman AM, Karasik D, Gruenthal KM, Demissie S, Cupples LA Housman DE, Kiel DP: Estrogen receptor beta polymorphisms are associated with bone mass in women and men: the Framingham Study. J Bone Miner Res 2004, 19:773-781.

25. Efstathiadou Z, Koukoulis G, Stakias N, Challa A, Zintzaras E, Tsatsoulis A: Correlation of estrogen receptor beta gene polymorphisms with spinal bone mineral density in peri- and post-menopausal Greek women. Maturitas 2006, 53:380-385.

26. van Meurs JB, Schuit SC, Weel AE, Klift M van der, Bergink AP, Arp PP, Colin EM, Fang Y, Hofman A, van Duijn CM, van Leeuwen JP, Pols HA, Uitterlinden AG: Association of 5' estrogen receptor alpha gene polymorphisms with bone mineral density, vertebral bone area and fracture risk. Hum Mol Genet 2003, I 2: I 745- I 754 .

27. Schuit SC, Oei HH, Witteman JC, Geurts van Kessel $\mathrm{CH}$, van Meurs JB, Nijhuis RL, van Leeuwen JP, de Jong FH, Zillikens MC, Hofman A, Pols HA, Uitterlinden AG: Estrogen receptor alpha gene polymorphisms and risk of myocardial infarction. JAMA 2004, 291:2969-2977.

28. Herrington DM, Howard TD, Brosnihan KB, McDonnell DP, Li X, Hawkins GA, Reboussin DM, Xu J, Zheng SL, Meyers DA, Bleecker ER: Common estrogen receptor polymorphism augments effects of hormone replacement therapy on E-selectin but not C-reactive protein. Circulation 2002, 105: |879-|882.

29. Schuit SC, van Meurs JB, Bergink AP, Klift M van der, Fang Y, Leusink $G$, Hofman A, van Leeuwen JP, Uitterlinden AG, Pols HA: Height in pre- and postmenopausal women is influenced by estrogen receptor alpha gene polymorphisms. J Clin Endocrinol Metab 2004, 89:303-309.

30. Schuit SC, de Jong FH, Stolk L, Koek WN, van Meurs JB, Schoofs MW, Zillikens MC, Hofman A, van Leeuwen JP, Pols HA, Uitterlinden AG: Estrogen receptor alpha gene polymorphisms are associated with estradiol levels in postmenopausal women. Eur J Endocrinol 2005, I 53:327-334.

3I. Lorentzon M, Lorentzon R, Bäckström T, Nordström P: Estrogen receptor gene polymorphism, but not estradiol levels, is related to bone density in healthy adolescent boys: a crosssectional and longitudinal study. J Clin Endocrinol Metab 1999 , 84:4597-460I.

32. Rapuri PB, Gallagher JC, Knezetic JA, Haynatzka V: Estrogen receptor alpha gene polymorphisms are associated with changes in bone remodeling markers and treatment response to estrogen. Maturitas 2006, 53:37I-379.

33. Boot AM, Sluis IM van der, de Muinck Keizer-Schrama SM, van Meurs JB, Krenning EP, Pols HA, Uitterlinden AG: Estrogen receptor alpha gene polymorphisms and bone mineral density in healthy children and young adults. Calcif Tissue Int 2004, 74:495-500.

34. Hall JM, McDonnell DP: The estrogen receptor beta-isoform (ERbeta) of the human estrogen receptor modulates ERalpha transcriptional activity and is a key regulator of the cel- 
lular response to estrogens and antiestrogens. Endocrinology 1999, 140:5566-5578.

35. Albagha OM, Ralston SH: Genetic determinants of susceptibility to osteoporosis. Endocrinol Metab Clin North Am 2003, 32:65-8I.

36. Cepollaro C, Lauretani F, Gozzini A, Masi L, Falchetti A, Del Monte F, Carbonell-Sala S, Tanini A, Corsi AM, Bandinelli S, Ferrucci L, Brandi ML: Relationship of volumetric bone mineral density and structural parameters with ERalpha gene polymorphisms. Calcif Tissue Int 2007, 80:307-3I5.

37. Morón FJ, Mendoza N, Vázquez F, Molero E, Quereda F, Salinas A, Fontes J, Martínez-Astorquiza T, Sánchez-Borrego R, Ruiz A: Multilocus analysis of estrogen-related genes in Spanish postmenopausal women suggests an interactive role of ESRI, ESR2 and NRIPI genes in the pathogenesis of osteoporosis. Bone 2006, 39:2I3-22I.

38. Rivadeneira F, van Meurs JB, Kant J, Zillikens MC, Stolk L, Beck TJ, Arp P, Schuit SC, Hofman A, Houwing-Duistermaat JJ, van Duijn CM, van Leeuwen JP, Pols HA, Uitterlinden AG: Estrogen receptor beta (ESR2) polymorphisms in interaction with estrogen receptor alpha (ESRI) and insulin-like growth factor I (IGFI) variants influence the risk of fracture in postmenopausal women. J Bone Miner Res 2006, 21: I 443-I456.

39. McGuigan FE, Murray L, Gallagher A, Davey-Smith G, Neville CE, Van't Hof R, Boreham C, Ralston SH: Genetic and environmenta determinants of peak bone mass in young men and women. J Bone Miner Res 2002, I7:1273-1279.

40. Valero C, Zarrabeitia MT, Hernández JL, Zarrabeitia A, GonzálezMacías J, Riancho JA: Bone mass in young adults: relationship with gender, weight and genetic factors. J Int Med 2005, 258:554-562.

4I. Sowers M, Jannausch ML, Liang W, Willing M: Estrogen receptor genotypes and their association with the 10 -year changes in bone mineral density and osteocalcin concentrations. J Clin Endocrinol Metab 2004, 89:733-739.

42. Ichikawa S, Koller DL, Peacock M, Johnson ML, Lai D, Hui SL, Johnston CC, Foroud TM, Econs MJ: Polymorphisms in the estrogen receptor beta (ESR2) gene are associated with bone mineral density in Caucasian men and women. J Clin Endocrinol Metab 2005, 90:5921-5927.

43. Maller J, George S, Purcell S, Fagerness J, Altshuler D, Daly MJ, Seddon $J M$ : Common variation in three genes, including a noncoding variant in CFH, strongly influences risk of age-related macular degeneration. Nat Genet 2006, 38: 1055- 1059.

Publish with Bio Med Central and every scientist can read your work free of charge

"BioMed Central will be the most significant development for disseminating the results of biomedical research in our lifetime. "

Sir Paul Nurse, Cancer Research UK

Your research papers will be:

- available free of charge to the entire biomedical community

- peer reviewed and published immediately upon acceptance

- cited in PubMed and archived on PubMed Central

- yours - you keep the copyright
BioMedcentral 